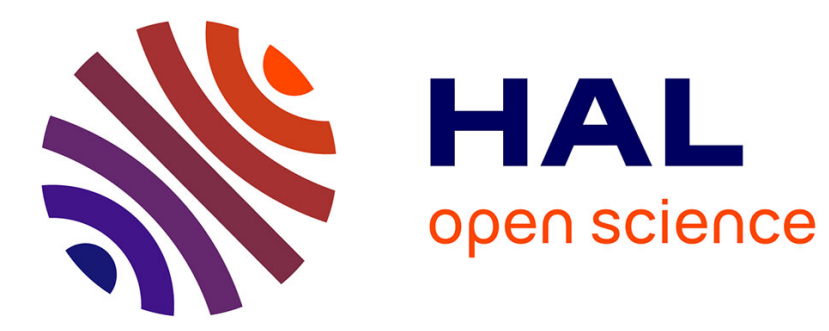

\title{
The effects of ovine growth hormone on protein turnover in rainbow trout
}

\author{
A.R. Foster, D.F. Houlihan, C. Gray, Françoise Médale, Benoit Fauconneau, \\ Sadasivam S. Kaushik, Pierre-Yves Le Bail
}

\section{- To cite this version:}

A.R. Foster, D.F. Houlihan, C. Gray, Françoise Médale, Benoit Fauconneau, et al.. The effects of ovine growth hormone on protein turnover in rainbow trout. General and Comparative Endocrinology, 1991, 82, pp.111-120. 10.1016/0016-6480(91)90302-M . hal-02713415

\section{HAL Id: hal-02713415 \\ https://hal.inrae.fr/hal-02713415}

Submitted on 1 Jun 2020

HAL is a multi-disciplinary open access archive for the deposit and dissemination of scientific research documents, whether they are published or not. The documents may come from teaching and research institutions in France or abroad, or from public or private research centers.
L'archive ouverte pluridisciplinaire HAL, est destinée au dépôt et à la diffusion de documents scientifiques de niveau recherche, publiés ou non, émanant des établissements d'enseignement et de recherche français ou étrangers, des laboratoires publics ou privés. 


\title{
The Effects of Ovine Growth Hormone on Protein Turnover in Rainbow Trout
}

\author{
A. R. Foster $, *, 1$ D. F. Houlihan,${ }^{*}$ C. Gray,${ }^{*}$ F. Medale,$\dagger$ B. Fauconneau,$\ddagger$ \\ S. J. KaUshik, $\dagger$ AND P. Y. Le BaIL $\ddagger$ \\ *Zoology Department, University of Aberdeen, Scotland, United Kingdom; †Fish Nutrition Research Unit, \\ Station d'Hydrobiologie, INRA, St Pée-sur-Nivelle, Ascain, France; and $\$$ Laboratoire de Physiologie des \\ Poissons, INRA, Campus de Beaulieu, 35042 Rennes, France
}

Accepted March 5, 1990

\begin{abstract}
Ovine growth hormone (oGH) was administered to rainbow trout via an intraperitoneal cholesterol implant. After 21 days, plasma oGH levels were recorded as control group, $<2$ $\mathrm{ng} \mathrm{ml} \mathrm{m}^{-1}$, i.e., not detectable, and $\mathrm{oGH}$ group, $19.2 \pm 2.8 \mathrm{ng} \mathrm{ml}^{-1}$. oGH-treated fish exhibited significantly increased whole-body growth rates, whole-body protein accretion rates, stimulated tissue protein synthesis, and tissue protein accretion rates. A dramatic decrease in white muscle protein concentration was also observed after oGH treatment. In some tissues (liver and stomach), elevated protein synthesis rates were the result of higher RNA/ protein ratios. However, in other tissues (gill and ventricle), increased RNA activity accounted for the differences in rates of protein synthesis. The growth promoting effects of oGH on both whole-body and tissue protein turnover were generally accompanied with no change in the efficiency of deposition of newly synthesized protein. For the same ration size, the oGH group showed higher retentions of ingested nitrogen. It is concluded that oGH significantly enhances whole-body growth rates as a result of the stimulatory effect on protein synthesis rates with little effect on protein degradation. (C) 1991 Academic Press, Inc.
\end{abstract}

The effects of mammalian growth hormone $(\mathrm{GH})$ on whole-body and tissue growth in teleosts are well documented (Weatherley and Gill, 1987; Donaldson et al., 1979; Gill et al., 1985). GH is known to stimulate appetite (Pickford and Atz, 1957; Higgs et al., 1975), food conversion efficiency (Markert et al., 1977), lipid mobilization (Sheridan, 1986), nitrogen retention (Matty, 1962), and amino acid incorporation into tissues (Cheema and Matty, 1978). Independent of these growth promoting effects, GH is also involved in the smoltification and seawater adaptability of salmonids (Bolton et al., 1987; Young et al., 1989) and in the production of antifreeze proteins in marine fish (Idler et al., 1989).

Much of the work on protein metabolism

\footnotetext{
${ }^{1}$ Present address: Rowett Research Institute, Aberdeen, Scotland, United Kingdom.
}

suggests that mammalian $\mathrm{GH}$ increases protein synthesis and thus whole-body growth rates of fish. Cheema and Matty (1978) demonstrated that porcine GH stimulated the in vivo incorporation of $\mathrm{L}$ $\left[{ }^{14} \mathrm{C}\right]$ leucine into the skeletal muscle of rainbow trout. Similarly, ovine growth hormone (oGH) administration to hypophysectomized eels resulted in an accelerated incorporation of radiolabeled leucine into liver and musclc protein (Inui and Ishioka, 1985). However, the conclusions drawn from these radiolabel incorporation studies are limited by problems of radiolabel excretion, and/or reutilization. Recently, quantitative protein synthesis measurements in fish have become feasible with the modification of the flooding dose technique (Houlihan et al., 1986, 1988, 1989), previously used to measure in vivo mammalian protein synthesis rates (Garlick et al., 1980). Fur- 
thermore, using the flooding dose technique, rates of protein degradation can be quantified as the difference between protein synthesis and protein accretion rates (Reeds et al., 1982). This study examines the effects of ovine GH administration on whole-body and tissue protein turnover in the rainbow trout, Oncorhyncus mykiss (formerly, Salmo gairdneri). In addition, the effects of oGH on tissue ribonucleic acid (RNA)/protein ratio, RNA concentration, and RNA activity have been investigated.

\section{MATERIALS AND METHODS}

Experimental design. This experiment was conducted at the INRA, Fish Nutrition Research Unit, St. Pée-sur-Nivelle, France, during April 1988. The fish in this study were underyearling rainbow trout of similar initial weight $(P=0.2635)$ and length $(P=0.3524)$. All fish were fed a diet of commercial pellets (Aqualim G.S.O., France, crude protein $52.5 \%$, gross energy 21 $\mathrm{kJ} / \mathrm{g}$ ). The water temperature was $11 \pm 1^{\circ}$. The fish were maintained under natural photoperiodic conditions for this time of year in 60-liter tanks supplied with free running water.

The animals in the control-implanted group (mean initial body weight \pm 1 SEM, $51.2 \mathrm{~g} \pm 1.1 ; n=17)$ each received a single cholesterol pellet ( $45 \mathrm{mg}$ cholesterol) containing no growth hormone. Cholesterol pellets were implanted, under anesthesia $(0.4 \%$ ethylene glycol monophenylether in water), into the peritoneal cavity of each fish (Higgs et al., 1975). A nonimplanted control group was also included to detcrmine the effects of cholesterol pellet implantation on wholebody, weight-specific growth rates $(53.8 \mathrm{~g} \pm 4.5, n=$ 34).

The growth hormone-implanted fish $(52.7 \mathrm{~g} \pm 0.9, n$ $=20)$ each received a similar cholesterol pellet $(45 \mathrm{mg})$ containing $1 \mathrm{mg}$ oGH (supplied by NHPP, a contract program of NIDDK, University of Maryland School of Medicine, batch No. oGH 13B14, purity $>99 \%$. One milligram oGH resulted in a dosage of $20 \mu \mathrm{g}$ oGH g fish $^{-1}$ at the beginning of the experiment.

The ration size consumed by the control group was calculated to be $2.50 \%$ body wt day ${ }^{-1}$ and the oGH group ration size was adjusted to be similar; it was $2.55 \%$ body wt day ${ }^{-1}$. Fish were maintained under these conditions for 21 days, after which whole-body growth rates over the 21-day period were calculated from (Ricker, 1979)

Specific growth rate $(\%$ day $)=$

$$
\frac{\left(\log e W_{2}-\log e W_{1}\right)}{t} \times 100,
$$

where $W_{1}(\mathrm{~g})$ was the initial weight, $W_{2}(\mathrm{~g})$ was the final weight, and $t$ was the length (in days) of the growing period.

Measurement of protein synthesis. Whole-body and tissue protein synthesis rates were measured using the flooding dose method (Houlihan et al., 1986, 1988, 1989). Twelve hours after the last meal, the animals were injected via the caudal vein without anesthesia. The injection solution contained $150 \mathrm{mM} \mathrm{L}$ phenylalanine and $\mathrm{L}-\left[2,6{ }^{3} \mathrm{H}\right]$ phenylalanine (Amersham Int.) at $37 \times 10^{6} \mathrm{~Bq} \mathrm{ml}^{-1}$ in Cortland Ringer at pH 7.4 (specific radioactivity, 1210 disintegrations per minute nmole phenylalanine ${ }^{-1}$, DPM $\mathrm{nmol}^{-1}$ ). The dosage was $1 \mathrm{ml}$ injection solution/100 $\mathrm{g}$ body $\mathrm{wt}^{-1}$. All injections were performed between 0900 and 1200 $\mathrm{hr}$, to avoid possible diel variations in protein synthesis rates.

Following the injection, the fish were returned to aerated water at the experimental temperature. After a 40-min incorporation period, the fish were killed by a sharp blow to the head and transection of the spinal cord.

After the incorporation period, the fish used for whole-body rates of protein synthesis were killed and immediately frozen whole in liquid nitrogen (control, $n$ $=7$; oGH implanted, $n=6$ ). The whole fish bodies were then freeze-dried and ground into powder. From the powder of each fish, three random samples were taken and used for the measurement of whole-body protein synthesis, $k_{\mathrm{s}}$ (percentage of whole-body protein mass synthesized day ${ }^{-1}$ ).

The remaining fish from each treatment group ( $n=$ 10) were used for tissue protein synthesis measurements. Ventricle, gill, liver, stomach, intestine, and white muscle were dissected from the fish. White muscle samples were standardized by taking all samples from the area below the dorsal fin. All dissections were performed on ice and tissue samples were immediately frozen in liquid nitrogen. Samples were then stored at $-20^{\circ}$ until analysis. Protein (Lowry et al., 1951) and RNA determinations (Mejbaum, 1939) were performed on the tissues within 3 days of storage at $-20^{\circ}$. RNA/protein ratios ( $\mu \mathrm{g}$ RNA mg protein ${ }^{-1}$ ) were calculated as proposed by Pain and Garlick (1974).

Fractional rates of protein synthesis, $k_{\mathrm{s}}$, in fish whole bodies and tissues were calculated using (Garlick et al., 1980)

Rate of protein synthesis, $k_{\mathrm{s}}=$

$$
\frac{S_{\mathrm{B}}}{S_{\mathrm{A}}} \times \frac{1440}{40} \times 100,
$$

where $S_{\mathrm{B}}$ and $S_{\mathrm{A}}$ are the specific radioactivities of the protein-bound and free-pool phenylalanine, respectively; 1440 is the number of minutes day ${ }^{-1}$, and $t$ is the incorporation period (in minutes). Protein synthesis measurements were made on 100-mg samples (wet 
weight) taken at random from each tissue; $100-\mathrm{mg}$ samples (freeze-dried) were also used for the wholebody measurements. Absolute amounts of protein synthesized ( $m g$ protein synthesized day $^{-1}$ ) in each tissue were calculated by multiplying total tissue protein content by the respective tissue $k_{\mathrm{s}}$.

The translational efficiency of the ribosomes, $k_{\mathrm{RNA}}$ (g protein synthesized g RNA ${ }^{-1}$ day $^{-1}$ ) was calculated by dividing tissue fractional protein synthesis rates by the respective RNA/protein ratio (Preedy et al., 1988).

Rates of protein accretion and degradation. To calculate individual tissue protein accretion rates, $k_{\mathrm{g}}$ (percentage of the protein mass deposited as growth day $^{-1}$ ), the tissue dissections from the control fish at the end of the experiment were used. It was assumed that tissue protein concentration did not change over the 21-day period.

Using these data, tissue protein contents (at the beginning of the experiment) could be estimated by multiplication of the estimated initial tissue weight by the mean tissue protein concentration. Initial whole-body protein contents were calculated by multiplication of initial body weight at time 0 with the mean whole-body protein concentration for the control fish. Thus, to calculate whole-body and tissue protein accretion rates for the experimental fish, initial (estimated) and final (measured) protein contents of each individual whole body (or tissue) were inserted into the specific growth rate equation (above). Four extra fish were added to the oGH whole-body group of fish to increase the sample size in this group. These fish were treated in an identical manner to all other oGH implanted fish except that they were fed a marginally larger ration size, $2.80 \%$ body wt day ${ }^{-1}$. The final sample size for the oGH whole-body data was therefore 10 animals.

Rates of protein degradation, $k_{\mathrm{d}}$ (percentage of whole-body or tissue protein mass degraded day $^{-1}$ ), were calculated as the diffcrence between the rates of protein synthesis and protein accretion (Millward and Waterlow, 1978; Reeds et al., 1982). The efficiency of deposition of newly synthesized protein (ED, percentage of the protein mass synthesized and subsequently deposited as protein growth day $^{-1}$ ) was calculated as $\left(k_{\mathrm{g}} / k_{\mathrm{s}}\right) \times 100$.

Body composition. Tissue somatic indices ((total tissue wt/body wt) $\times 100)$ were calculated. Tissue $/$ whole-body compositions were also calculated as (total tissue protein content)/(total individual fish wholebody protein content) $\times 100$. Tissue/body composition was calculated in this way to avoid possible bias as a result of differences in tissue composition (i.e., water, lipid) between treatment groups.

Ovine GH assay. At the end of the 21-day experiment, blood samples were taken from the caudal vasculature of the fish, immediately prior to sacrifice using nonheparinized syringes. The blood was allowed to clot overnight at $4^{\circ}$ before centrifugation at $3500 \mathrm{~g}$. Plasma samples were then stored at $-20^{\circ}$ until oGH measurement by RIA. Ovine GH was measured using a mammalian RIA (sensitivity, $2 \mathrm{ng}$ oGH ml-1 plasma), and crossreactivity with trout $\mathrm{GH}$ was $<1 \%$ (Le Bail et al., 1989).

Statistics. All statistical comparisons were made using Student's unpaired $t$ test (Zar, 1974). Tissuesomatic indices were arcsine transformed before testing for differences (Zar, 1974). Significance was taken at $P \leq 0.05$.

\section{RESULTS}

\section{Plasma oGH, Whole-Body Growth Rates, and Protein Synthesis}

The nonimplanted control group and the implanted control group showed similar whole-body growth rates (nonimplanted $1.94 \pm 0.32$, implanted $1.80 \pm 0.14 \%$ day ${ }^{-1}$ ). Thus, it was concluded that cholesterol pellet implantation had no significant effect on the whole-body growth rate of the trout. The cholesterol-implanted control and cholesterol/oGH-implanted fish could therefore be directly compared.

Plasma oGH measurements were recorded as control, $<2 \mathrm{ng} \mathrm{ml}^{-1}, n=10$, i.e., not detectable, and oGH group, $19.2 \pm 2.8$ ng $\mathrm{ml}^{-1}, n=10$. Therefore, oGH/ cholesterol pellet implantation allowed the significant release of oGH into the plasma.

Ovine $\mathrm{GH}$ administration increased both weight-specific growth rate $(P<0.01)$ and percentage length increase $(P<0.001)$ compared to the implanted control group (Table 1). Whole-body growth rates and whole-body protein accretion rates were similar within each treatment group (Table 1). Also, oGH whole-body protein accretion rates were higher than in the control fish $(P<0.01)$. However, oGH had no significant effects on whole-body rates $k_{\mathrm{s}}, k_{\mathrm{d}}$, or ED, compared to the control fish (Table 1).

Whole-body and tissue free-pool specific radioactivities, $S_{\mathrm{A}}$ (DPM nmol phenylalanine $^{-1}$ ), were slightly lower than the specific radioactivity of the injected solution (Table 2). Moreover, free-pool specific radioactivities were similar both between whole-bodies, tissues and between treat- 
TABLE 1

SUMMARY OF WHOLE-BODY (WB), WeIGHT-SPECIFIC GROWTH RATE (SGR), Percentage Increase in Length, Whole-Body Protein Accretion Rate $\left(k_{\mathrm{g}}\right)$ Whole-Body Protein Synthesis $\left(k_{\mathrm{s}}\right)$, Whole-Body Protein Degradation $\left(k_{\mathrm{d}}\right)$, AND THE EFFICIENCY OF Protein Deposition (ED) (Percentage Synthesised Protein Deposited as Growth DAY ${ }^{-1}$ ) OF THE ANIMALS USED FOR THE WhOLE-BODY ANALYSES

\begin{tabular}{lccc}
\hline & Implanted & $\begin{array}{c}\text { oGH-implanted } \\
\text { control }\end{array}$ \\
\hline Whole body SGR & $1.80 \pm 0.22$ & $2.78^{*}$ & \pm 0.10 \\
\% increase in length & $8.01 \pm 2.68$ & $13.21^{* *} \pm 2.47$ \\
WB protein k $_{\text {g }}$ & $1.80 \pm 0.14$ & $2.66^{*}$ & \pm 0.15 \\
WB k $_{\mathrm{s}}$ & $4.39 \pm 0.45$ & 5.13 & \pm 0.25 \\
WB k & $2.58 \pm 0.54$ & 2.39 & \pm 0.28 \\
WB ED & $45.25 \pm 7.33$ & 53.12 & \pm 3.80 \\
\hline
\end{tabular}

Note. Statistical comparisons were made using Student's unpaired $t$ test where ${ }^{*} P<0.01$ and ${ }^{* * *} P<$ 0.001 . Values are means \pm 1 SEM. Sample sizes were control, $n=7$; oGH, $n=10$.

ment groups. Thus, it was concluded that the injection solution contained sufficient phenylalanine for the equilibration and maintenance of stable free-pool specific radioactivities. This finding was consistent with other studies (Houlihan et al., 1986, 1988, 1989) where a 40-min incorporation period was suitable for measuring wholebody and tissue protein synthesis rates.

\section{TABLE 2}

Whole-Body and Tissue Free-Pool Specific RADIOACTIVITIES $S_{\text {A }}$ (DPM NMOL

PhenYlalanine $^{-1}$ ) Following INJection of $\left[{ }^{3} \mathrm{H}\right]$ Phenylalanine

\begin{tabular}{lrrr}
\hline \multicolumn{1}{c}{ Tissue } & \multicolumn{1}{c}{ Control } & \multicolumn{1}{c}{ oGH implanted } \\
\cline { 1 - 1 } Whole-body & $933.7 \pm 50.0$ & & $1001.0 \pm 32.3$ \\
Ventricle & $1130.5 \pm 13.0$ & & $1159.3 \pm 19.6$ \\
Gill & $1089.0 \pm 26.3$ & & $1113.8 \pm 31.2$ \\
Liver & $976.8 \pm 14.4$ & $1012.5 \pm 18.2$ \\
Stomach & $1029.3 \pm 61.5$ & $1028.1 \pm 22.7$ \\
Intestine & $884.5 \pm 19.0$ & $943.9 \pm 26.9$ \\
White muscle & $1025.4 \pm 23.4$ & $1089.4 \pm 20.5$ \\
\hline
\end{tabular}

Note. Within any one tissue, no significant differences in free-pool specific radioactivity were found between treatment groups. The specific radioactivity of the injection solution was 1210 DPM nmol phenylalanine ${ }^{-1}$. Values are means \pm 1 SEM. Sample size was 10 in each group.
The free-phenylalanine levels (nmol phenylalanine $g$ tissue ${ }^{-1}$ ) determined in the white muscle indicated that the high dose of phenylalanine raised the free phenylalanine concentration approximately 17 -fold from the assumed normal level of $90 \mathrm{nmol}$ phenylalanine $\mathrm{g}$ white muscle ${ }^{-1}$ (Mommsen et al., 1980). Assuming that all of the injected phenylalanine was equally distributed throughout the body, the injection of 135 $\mu \mathrm{mol} 100 \mathrm{~g}^{-1}$ animal should result in a free phenylalanine concentration of $1440 \mathrm{nmol} \mathrm{g}$ tissue $^{-1}$ (including endogenous phenylalanine). It is worthwhile noting that the measured white muscle phenylalanine concentrations were in agreement with this prediction (control, $1529.5 \pm 133.2, N=10 ; \mathrm{oGH}$ implanted, $1557.4 \pm 43.4 \mathrm{nmol}$ phenylalanine $\mathrm{g}$ white muscle ${ }^{-1}, n=10$ ). Thus, the radiolabel appeared to have equilibrated throughout the tissues of the fish within the 40-min incorporation period.

\section{Tissue Protein Growth}

Whole-body growth rates of the oGH trout used for the tissue analyses were also stimulated compared to the implanted control fish $(\mathrm{SGR}=2.47 \pm 0.06, n=10, P<$ 0.001 ).

Tissue protein concentrations (mg protein $\mathrm{g}$ tissue ${ }^{-1}$ ) were similar between tissues, regardless of treatment group (Table 3 ). The only exception to this was the oGH group white muscle where the protein concentration was lower $(P<0.01)$ compared to the control group. As a result of the lower oGH white muscle protein concentration, white muscle protein accretion rates could not be accurately determined and have thus been omitted.

Ventricle demonstrated mass hypertrophy $(P<0.05)$ following oGH administration (percentage wet body wt) (Table 3 ). The remainder of the tissues demonstrated either no change (gill, stomach and intestine) or a significant decrease (liver and white muscle, $P<0.05$ ) with oGH treatment.

When the data were reexpressed (total 
TABLE 3

Tissue Protein Concentration (P Concentration, mg Protein g Tissue ${ }^{-1}$ ) Tissue-Somatic Indices (TSI, Percentage Wet body Wt), Tissue Protein Content (TPC, Expressed as a Percentage of Whole-Body Protein Content) in the Cholesterol (Control) and Cholesterol/oGH (oGH) IMPLANTED GROUPS

\begin{tabular}{|c|c|c|c|c|}
\hline Tissue & $\begin{array}{c}\mathrm{P} \\
\text { concentration }\end{array}$ & $\%$ TSI & $\% 1$ & ГРС \\
\hline \multicolumn{5}{|l|}{ Ventricle } \\
\hline Control & \pm 5.38 & $0.129 \pm 0.008$ & 0.122 & \pm 0.008 \\
\hline oGH implant & \pm 3.60 & $0.153^{*} \pm 0.008$ & 0.144 & \pm 0.009 \\
\hline \multicolumn{5}{|l|}{ Liver } \\
\hline Control & \pm 4.46 & $1.56 \pm 0.08$ & 1.63 & \pm 0.09 \\
\hline oGH implant & \pm 3.55 & $1.34^{*} \pm 0.06$ & 1.59 & \pm 0.07 \\
\hline \multicolumn{5}{|l|}{ Stomach } \\
\hline Control & \pm 8.22 & \pm 0.18 & 2.86 & \pm 0.30 \\
\hline oGH implant & \pm 4.53 & $2.75 \pm 0.14$ & 2.63 & \pm 0.19 \\
\hline \multicolumn{5}{|l|}{ Intestine } \\
\hline Control & \pm 6.88 & \pm 0.10 & 1.33 & \pm 0.10 \\
\hline oGH implant & \pm 4.37 & \pm 0.08 & 1.41 & \pm 0.10 \\
\hline \multicolumn{5}{|l|}{ Gill } \\
\hline Control & $78.82 \pm 3.45$ & \pm 0.22 & 1.00 & \pm 0.08 \\
\hline oGH implant & $76.96 \pm 3.26$ & \pm 0.13 & 1.11 & \pm 0.04 \\
\hline \multicolumn{5}{|l|}{ White muscle } \\
\hline Control & $181.99 \pm 5.32$ & $46.46 \pm 0.82$ & 64.36 & \pm 1.88 \\
\hline oGH implant & $160.37^{* *} \pm 5.12$ & $42.71^{*} \pm 0.84$ & $56.64^{* *}$ & \pm 1.81 \\
\hline
\end{tabular}

Note. ${ }^{*}$ denotes a significant difference $(P<0.05)$ between the control and oGH group, and ${ }^{* *} P<0.01$. Values are means \pm 1 SEM. Sample sizes were 10 animals in each group.

tissue protein content/whole-body protein content), no differences in tissue/wholebody protein content were observed, except for white muscle (Table 3). White muscle/whole-body protein content decreased significantly $(P<0.01)$ due to oGH treatment. This decrease in oGH white muscle/ whole-body protein content was presumably a result of the lower white muscle protein concentration.

\section{Tissue Protein Accretion, Synthesis, and Degradation}

Ventricle, intestine, and gill showed $k_{\mathrm{g}}$ similar to the whole-body growth rates, indicating that these tissues were probably growing isometrically (Table 4). The control stomach protein accretion rates were lower than whole-body protein accretion rates. oGH liver and stomach protein accretion rates were also lower than the whole-body protein accretion rate.

Following oGH administration, tissue $k_{\mathrm{s}}$ was significantly elevated, in the majority of tissues examined (Fig. 1a). This stimulation in tissue $k_{\mathrm{s}}$ was tissue specific, ranging from $22 \%$ in the liver to $63 \%$ in the stomach. However, white muscle fractional protein synthesis rates were found to be very low (control, $0.21 \pm 0.03$; oGH, $0.29 \pm$ $0.08 \% \mathrm{day}^{-1}$ ). In absolute terms, oGH treatment also resulted in more protein being synthesized in most tissues (Fig. 1b).

Ovine growth hormone increased the protein degradation rate in the stomach (Table 4), therefore resulting in the low protein accretion rate observed for that tissue. Gill protein degradation was also higher in the oGH group compared to the controls ( $P$ $<0.05$ ). In the remaining tissues, protein degradation rates were similar regardless of treatment.

The ED for most of the tissues was not significantly different (data not shown) following oGH administration. The one exception to this was oGH stomach where ED was significantly lower $(P<0.05)$. 
TABLE 4

Tissue Protein Accretion Rates

$\left(k_{\mathrm{g}}\right.$, Percentage Protein Mass Accreted Day ${ }^{-1}$ ) and Protein Degradation $\left(k_{\mathrm{d}}\right.$, Percentage

Protein Mass Degraded Day ${ }^{-1}$ ) after

Cholesterol (Control) and ChOlesterol/oGH (oGH) Pellet Implantation

\begin{tabular}{|c|c|c|c|c|}
\hline \multirow{2}{*}{$\frac{\text { Tissue }}{\text { Ventricle }}$} & \multicolumn{2}{|c|}{$\begin{array}{l}\text { Protein accretion } \\
\text { rate } k_{\mathrm{g}}\end{array}$} & \multicolumn{2}{|c|}{$k_{\mathrm{d}}$} \\
\hline & & & & \\
\hline Control & 1.73 & \pm 0.13 & 1.71 & \pm 0.32 \\
\hline oGH & 2.46 & \pm 0.21 & 2.23 & \pm 0.38 \\
\hline \multicolumn{5}{|l|}{ Liver } \\
\hline Control & 1.82 & \pm 0.23 & 12.89 & \pm 1.06 \\
\hline oGH & $2.04^{*}$ & \pm 0.16 & 15.70 & \pm 1.45 \\
\hline \multicolumn{5}{|l|}{ Stomach } \\
\hline Control & $1.25^{*}$ & \pm 0.24 & 3.43 & \pm 1.06 \\
\hline oGH & $1.16^{* *}$ & \pm 0.24 & $6.16^{* * *}$ & \pm 0.62 \\
\hline \multicolumn{5}{|l|}{ Intestine } \\
\hline Control & 1.88 & \pm 0.27 & 13.36 & \pm 1.76 \\
\hline oGH & 2.60 & \pm 0.24 & 12.36 & \pm 1.93 \\
\hline \multicolumn{5}{|l|}{ Gill } \\
\hline Control & 1.71 & \pm 0.16 & 8.68 & \pm 0.71 \\
\hline oGH & 2.47 & \pm 0.13 & $11.44^{* * *}$ & \pm 0.95 \\
\hline
\end{tabular}

Note. ${ }^{*}$ denotes a significant difference between the whole-body and tissue protein accretion rates $\left(k_{\mathrm{g}}\right)$ at $(P$ $<0.05)$ and ${ }^{* *}$ denotes a significant difference between whole-body and tissue protein accretion rates at $(P<0.001),{ }^{* * *}$ denotes significant difference between control and oGH group at $P<0.05$. Values are means \pm 1 SEM. Sample size was 10 in each group.

\section{Tissue RNA Concentration, RNA/Protein Ratio, and RNA Activity}

RNA/protein ratios of ventricle and intestine were higher in the oGH group (at least $P<0.05)$ compared with the control fish (Fig. 2a). The oGH white muscle RNA/ protein ratio was also significantly stimulated (control, $8.13 \pm 0.43, \mathrm{oGH}, 11.35 \pm$ $0.81, P<0.01$ ). The greater oGH white muscle RNA/protein ratio was due to an increased RNA concentration $(P<0.025)$ and not only a result of the decreased white muscle protein concentration. In the remaining oGH tissues, the RNA concentration tended to be higher, although not significant, than in the control group.

Tissue $k_{\mathrm{RNA}}$ appeared to be stimulated by
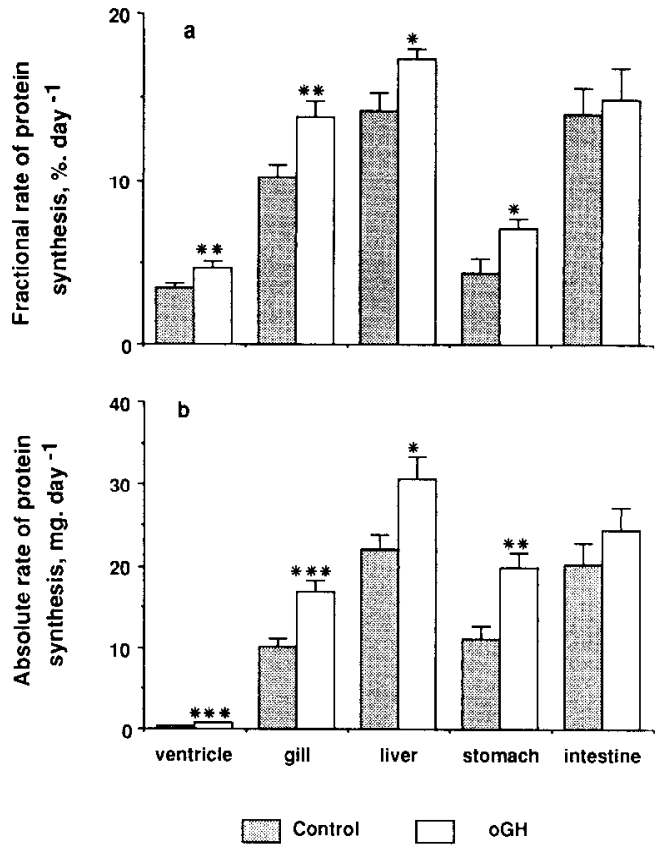

Fig. 1. (a) Tissue fractional protein synthesis rates, $k_{\mathrm{s}}$ (percentage protein mass synthesized day ${ }^{-1}$ ), after cholesterol pellet (control) and cholesterol pellet/oGH implantation (oGH). Where * denotes a significant difference between the control and oGH group at $P<$ 0.05 , and ${ }^{* *} P<0.01$. Each point represents mean \pm $1 \mathrm{SEM}$ of 10 fish. (b) Absolute amounts (mg) of protein synthesized in each tissue day $^{-1}$, following cholesterol pellet (control) and cholesterol pellet/oGH implantation (oGH). Where ${ }^{*}$ denotes a significant difference between the control and oGH group at $P<$ $0.05,{ }^{* *} P<0.01$, and ${ }^{* * *} P<0.001$. Each point represents mean \pm 1 SEM of 10 fish.

oGH (Fig. 2b), although only ventricle and gill reached significance $(P<0.02)$.

\section{DISCUSSION}

\section{Methodology}

It has been shown that the injection of a flooding (high) dose of amino acid does not affect the rate of protein synthesis in either mammals or fish (McNurlan et al., 1979; Loughna and Goldspink, 1985). However, in the present study little radiolabel was incorporated into white muscle protein during the 40-min incorporation period. Thus, longer incorporation periods may be neces- 

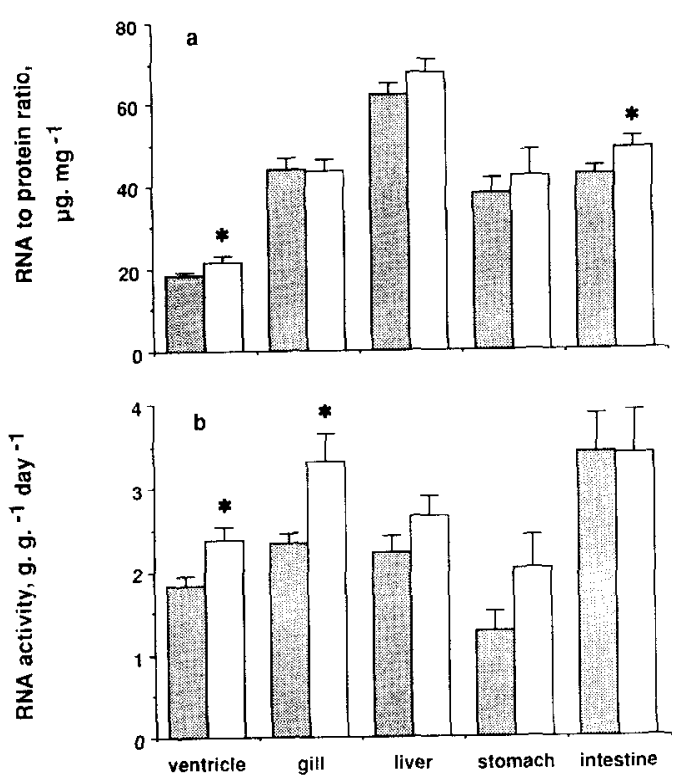

Control $\square$ oGH

FIG. 2. (a) Tissue RNA/protein ratios ( $\mu \mathrm{g}$ RNA mg protein $^{-1}$ ) after cholesterol pellet (control) and cholesterol pellet/oGH implantation (oGH). Where ${ }^{*}$ denotes a significant difference between the control and oGH group at $P<0.05$ and ${ }^{* *}$ at $P<0.01$. Each point represents mean \pm 1 SEM of 10 fish. (b) Tissue RNA activity, $k_{\mathrm{RNA}}$ ( $\mathrm{g}$ protein synthesized $\mathrm{g} \mathrm{RNA}^{-1}$ day $^{-1}$ ), following cholesterol pellet (control) and cholesterol pellet/oGH implantation (oGH). Where * denotes a signiticant difference between the control and oGH group at $(P<0.02)$. Each point represents mean \pm 1 SEM of 10 fish.

sary for the quantitative measurement of white muscle protein synthesis rates in fish.

Problems with estimating protein degradation rates from the difference between protein synthesis and protein accretion rates have been discussed previously (Reeds et al., 1986; Houlihan and Laurent, 1987; Houlihan et al., 1988). However, as alternative methods for measuring protein degradation were unavailable, it was convenient to cautiously use this method.

In the present study, the release of oGH into the plasma indicates that the dosage of oGH used was sufficient to maintain high growth rates for at least 3 weeks. Thus, cholesterol pellet implantation appears to be a good method for the administration of exogcnous GH without the stress of frequent handling (Kawauchi et al., 1986).

\section{Effects of oGH on Body Composition and Protein Turnover}

A dramatic decline in white muscle protein concentration and the contribution of white muscle to the whole-body protein content was observed following oGH treatment. One possible explanation for the lower white muscle protein concentration following $\mathrm{oGH}$ administration may have been the replacement of muscle protein by water. White muscle and liver somatic indices (percentage wet whole-body wt) also decreased with oGH treatment. The lower muscle and liver somatic indices (percentage wet wt) may be due to the lipolytic effects of GH in many tissues (Higgs et al., 1975; Sheridan, 1986).

The results of this study conclusively demonstrate that $\mathrm{oGH}$ has significant effects on both protein synthesis and, to a lesser extent, protein degradation in rainbow trout tissues. The observed stimulatory effects of oGH on protein synthesis are in agreement with earlier radiolabel incorporation studies (Cheema and Matty, 1978; Inui and Ishioka, 1985).

In a growing animal, increased protein accretion rates are generally the result of both increased protein synthesis and, to a lesser degree, increased protein degradation rates (Millward et al., 1975; Houlihan and Laurent, 1987; Houlihan et al., 1988). However, in the present study, higher whole-body protein accretion rates were not accompanied by significantly increased protein synthesis or degradation rates. The differences in whole-body protein accretion rates between the control and oGH groups may have been too small to result in a significant difference in whole-body protein degradation. However, this does not explain the lack of a stimulation in wholebody protein synthesis with oGH admin- 
istration. Thus, the whole-body protein turnover data gave us no satisfactory explanation of how the oGH group can grow faster when receiving the same ration size. It may be that we are witnessing a problem with measuring protein synthesis rates over a time scale of minutes and protcin accretion rates over days. However, it is feasible that a marginal increase in protein synthesis may account, within several days, for a significant increase in protein accretion. Since tclcosts are generally $50-65 \%$ white muscle (percentage wet wt), the low white muscle $k_{\mathrm{s}}$ may also have resulted in the underestimation of the effects of oGH on whole-body $k_{\mathrm{s}}$. Consequently, data on the effects of oGH on whole-body protein turnover may be incorrect. Also, it is interesting to note that although both treatment groups received the same ration size, the oGH group had higher retentions of ingested nitrogen, i.e., food conversion efficiencies.

In contrast to the whole-body protein turnover data, most oGH tissues (except intestine) exhibited higher protein synthesis rates, although increased protein degradation rates were only observed in gill and stomach. The lack of a general stimulation of protein degradation with oGH treatment may be due to the significant, yet relatively small, difference between the control and oGH tissue protein accretion rates. Thus, the increased tissue protein synthesis rates with no change in protein degradation give us a clear indication of how the higher tissue protein accretion was achieved.

In mammals, GH is known to have rapid (direct) effects on protein synthesis in liver and muscle, i.e., $30 \mathrm{~min}$ after hormone treatment (Koysto and Nutting, 1974). However, the growth promoting effects of $\mathrm{GH}$ also appear to be mediated, at least in part, by insulin-like growth factors (IGFs), previously termed somatomedins (Salmon and Daughaday, 1957). Since intact, i.e., nonhypophysectomized, fish were used in the present study, a part of the oGH effect may have been mediated by IGFs.

\section{Effects of oGH on Tissue RNA Concentration, RNA/Protein Ratio, and RNA Activity}

In vertebrates, protein synthesis rates are altered by both ribonucleic acid concentration and activity (Henshaw et al., 1971; McMillan and Houlihan, 1988). In the present study, oGH administration only increased white muscle RNA concentration. Similarly, bovine growth hormone (bGH) has been observed to increase liver (Venugopalan, 1967) and muscle RNA concentration in fish (Kayes, 1979).

Tissue $\mathrm{RNA}$ /protein ratios are used as an index of a tissues' capacity for protein synthesis (Preedy and Garlick, 1988). Therefore, the higher $\mathrm{RNA}$ /protein ratios in the oGH ventricle, intestine, and white muscle (Fig. 2a) indicated that the $k_{\mathrm{s}}$ in these tissues may be higher than in the control fish. However, this was only found to be true for ventricle. The low white muscle and variable intestine $k_{\mathrm{s}}$ probably obscured the effects of oGH on protein synthesis in these tissues.

Few studies have addressed the effects of GH on RNA activity in fish. In this study, tissue RNA activities, $k_{\mathrm{RNA}}$, were ranked as follows, intestine $>$ gill $>$ liver $>$ ventricle $>$ stomach. Ovine growth hormone treatment did not change the ranking of tissue RNA activity. However, oGH did increase RNA (translational) activities in both gill and ventricle.

The overall effects of oGH on protein synthesis and RNA concentration/activity in rainbow trout are consistent with the mammalian literature. Thus, in mammals, $\mathrm{GH}$ increases protein synthesis rates by stimulating the efficiency of ribosomal translation, as well as by increasing ribosomal and messenger RNA concentration (Manchester, 1976). 
To summarize, oGH administration had dramatic effects on whole-body growth and tissue protein synthesis rates in rainbow trout. Enhanced protein synthesis rates were the result of increased RNA/protein ratio and RNA activity. Moreover, for the same ration size, the oGH group had a greater efficiency of retention of ingested nitrogen and reduced nitrogen losses. However, it is unclear whether the observed changes in whole-body growth, tissue RNA concentration, RNA activity, and protein turnover represent the direct and/or indirect effects of GH and/or IGF action, respectively.

\section{ACKNOWLEDGMENTS}

Special thanks to Drs. D. N. McMillan and S. J. Hall for helpful discussions during the preparation of this manuscript. A.R.F, was in receipt of an NERC CASE Award, D.F.H. thanks the Royal Society for the contribution of a Travel Grant.

\section{REFERENCES}

Bolton, J. P., Collie, N. L., Kawauchi, H., and Hirano, T. (1987). Osmoregulatory actions of growth hormone in rainbow trout (Salmo gairdneri). J. Endocrinol. 112, 63-68.

Cheema, I. R., and Matty, A. J. (1978). Increased uptake of L-leucine $-{ }^{14} \mathrm{C}$ in the skeletal muscle of rainbow trout, Salmo gairdneri, after administration of growth hormone. Pak. J. Zool. 10, 119123.

Donaldson, E. M., Fagerlund, U. H. M., Higgs, D. A., and McBride, J. R. (1979). Hormonal enhancement of growth. Fish Physiol. 8, 455-597.

Garlick, P. J., McNurlan, M. A., and Preedy, V. R. (1980). A rapid and convenient technique for measuring the rate of protein synthesis in tissues by injection of ${ }^{3} \mathrm{H}$ phenylalanine. Biochem. J. 217, 507-516.

Gill, J. A., Sumpter, J. P., Donaldson, E. M., Dye, H. M., Souza, L., Berg, T., Wypych, J., and Langley, K. (1985). Recombinant chicken and bovine growth hormones accelerate growth in aquacultured juvenile pacific salmon, Oncorhynchus kisutch. Biotechnology 3, 643-646.

Henshaw, E. C., Hirsch, C. A., Morton, B. E., and Hiatt, B. M. (1971). Control of protein synthesis in mammalian tissues through changes in ribosome activity. J. Biol. Chem. 246, 436-446.
Higgs, D. A., Donaldson, E. M., Dye, H. M., and McBride, J. R. (1975). A preliminary investigation of the effect of bovine growth hormone on growth and muscle composition of coho salmon (Oncorhynchus kisutch). Gen. Comp. Endocrinol. 27, 240-253.

Houlihan, D. F., McMillan, D. N., and Laurent, P. (1986). Growth rates, protein synthesis, and protein degradation rates in rainbow trout: Effects of body size. Physiol. Zool. 59, 482-493.

Houlihan, D. F., and Laurent, P. (1987). Effects of exercise training on the performance, growth, and protein turnover of rainbow trout (Salmo gairdneri). Canad. J. Fish. Aquat. Sci. 44, 1614-1621.

Houlihan, D. F., Hall, S. J., Gray, C., and Noble, B. S. (1988). Growth rates and protein turnover in cod, Gadus morhus. Canad. J. Fish. Aquat. Sci. 45, 951-964.

Houlihan, D. F., Hall, S. J., and Gray, C. (1989). Effects of ration on protein turnover in cod. Aquaculture 79, 103-110.

Idler, D. R., Fletcher, G. L., Belkhode, S., King, M. J., and Hwang, S. J. (1989). Regulation of antifreeze protein production in winter flounder: A unique function for growth hormone. Gen. Comp. Endocrinol. 74, 327-334.

Inui, Y., and Ishioka, H. (1985). In vivo and in vitro effects of growth hormone on the incorporation of $\left[{ }^{14} \mathrm{C}\right]$ leucine into protein of liver and muscle of the eel. Gen. Comp. Endocrinol. 59, 295-300.

Kawauchi, H., Mosiyama, S., Yasuda, A., Yamachuchi, Y., Shirahata, K., Kubota, J., and Hirano, T. (1986). Isolation and characterization of chum salmon growth hormone. Arch. Biochem. Biophys. 244, 542-552.

Kayes, T. (1979). Effects of hypophysectomy and beef growth hormone replacement therapy, over time and at various dosages, on body weight and total RNA-DNA levels in the black bullhead. Gen. Comp. Endocrinol. 37, 321-332.

Koysto, J. L., and Nutting, D. F. (1974). Growth hormone and protein metabolism In "Handbook of Physiology' (S. R. Geiger, Ed.), Vol. 4, pp. 187210. Williams \& Wilkins, Baltimore.

Le Bail, P. Y., Sire, M. F., and Vernier, J. M. (1989). Intestinal transfer of growth hormone into the circulatory system of the rainbow trout, Salmo gairdneri: Interference by granule cells. J. Exp. Zool. 251, 101-107.

Loughna, P. T., and Goldspink, G. (1985). Muscle protein synthesis rates during temperature acclimation in a eurythermal (Cyprinus carpio) and a stenothermal (Salmo gairdneri) species of teleost. J. Exp. Biol. 118, 267-276.

Lowry, O. H., Rosebrough, N. J., Farr, A. L., and Randall, R. J. (1951). Protein measurements with 
the Folin phenol reagent. J. Biol. Chem. 193, 265275.

Manchester, K. L. (1976). Hormonal control of protein metabolism. In "Protein Metabolism and Nutrition"' (D. J. A. Cole, K. N. Boorman, P. J. Buttery, D. Lewis, R. J. Neale, and H. Swan, Eds.), pp. 35-48. Butterworths, Boston.

Markert, J. R., Higgs, D. A., Dye, H. M., and Macquarrie, D. W. (1977). Influence of bovine growth hormone on growth rate, appetite and food conversion of yearling coho salmon fed two diets of different composition. Canad. J. Zool. 55, 74-83.

Matty, A. J. (1962). Effects of mammalian growth hormone on Cottus scorpius blood. Nature (London) 195, 506-507.

McMillan, D. N., and Houlihan, D. F. (1988). The effect of re-feeding on tissue protein synthesis in rainbow trout. Physiol. Zool. 61, 429-441.

McNurlan, M. A., Tomkins, A. M., and Garlick, P. J. (1979). The effect of starvation on the rate of protein synthesis in rat liver and small intestine. Biochem. J. 178, 373-379.

Mejbaum, W. (1939). Uber der Bestimmung kleiner Pentosemengen, insbesondere in Derivaten der Adenylsaure. Hoppe-Seyler's Z. Physiol. Chem. 258, 117-120.

Millward, D. J., Garlick, P. J., Stewart, R. J. C., Nnanyelugo, and Waterlow, J. C. (1975). Skeletal muscle growth and protein turnover. Biochem. $J$. 150, 235-243.

Millward, D. J., and Waterlow, J. C. (1978). Effect of nutrition on protein turnover in skeletal muscle. Fed. Proc. 37, 2283-2290.

Mommsen, T. P., and French, C. J., and Hochachka, P. W. (1980). Sites and patterns of protein and amino acid utilisation during the spawning migration of salmon. Canad. J. Zool. 58, 1785-1799.

Pain, V. M., and Garlick, P. J. (1974). Effect of streptozotocin diabetes and insulin treatment on the rate of protein synthesis in tissues of the rat in vivo. J. Biol. Chem. 249, 4510-4514.

Pickford, G. E., and Atz, J. W. (1957). The Physiology of the Pituitary Gland of Fishes, pp. 1-91. New York Zoological Society, New York.

Preedy, V. R., and Garlick, P. J. (1988). The influence of restraint and infusion on rates of muscle protein synthesis in the rat. Biochem. J. 251, 577-580.

Preedy, V. R., Paska, L., Sugden, P. H., Schofield, P. S., and Sugden, M. C. (1988). The effects of surgical stress and short-term fasting on protein synthesis in vivo in diverse tissues of the mature rat. Biochem. J. 250, 179-188.

Reeds, P. J., Haggarty, P., Wahle, K. W. J., and Fletcher, J. M. (1982). Tissue and whole-body protein synthesis in immature Zucker rats and their relationship to protein deposition. Biochem. J. 204, 393-398.

Reeds, P. J., Palmer, R. M., Hay, S. M., and McMillan, D. N. (1986). Protein synthesis in skeletal muscle measured at different times during a 24 hour period. Biosci. Rep. 6, 209-213.

Ricker, W. E. (1979). Growth rates and models. In "Fish Physiology" (W. S. Hoar, D. J. Randall, and J. R. Brett, Ed.), Vol. 8, pp. 677-743. Academic Press, New York.

Salmon, W. D., Jr., and Daughaday, W. H. (1957). A hormonally controlled serum factor which stimulates sulphate incorporation by cartilage in vitro. J. Lab. Clin. Med. 49, 825-836.

Sheridan, M. A. (1986). Effects of thyroxin, cortisol, growth hormone, and prolactin on lipid metabolism of coho salmon, Oncorhynchus kisutch, during smoltification. Gen. Comp. Endocrinol. 64, 220-238.

Venugopalan, V. K. (1967). Effect of growth hormone injection on the level of nucleic acids in the liver of intact fish (Ophicephalus striatus). Gen. Comp. Endocrinol. 8, 332-336.

Weatherley, A. H., and Gill, H. S. (1987). Influence of Hormones. In "The Biology of Fish Growth," Chap. 6, pp. 177-427. Academic Press, New York.

Young, G., Bjornsson, B. T., Prunet, P., Lin, R. J., and Bern, H. A. (1989). Smoltification and seawater adaptation in coho salmon: Plasma prolactin, growth hormone, thyroid hormones, and cortisol. Gen. Comp. Endocrinol. 74, 335-345.

Zar, J. H. (1974). "Biostatistical Analysis." PrenticeHall, Englewood Cliffs, NJ. 